\title{
RECOMANDĂRI PRE-PROCEDURALE ÎN ENDOSCOPIA DIGESTIVĂ LA PACIENTUL PEDIATRIC
}

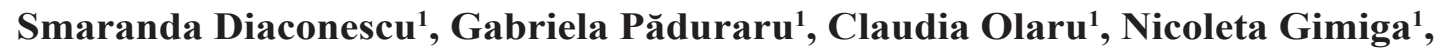 \\ Camelia Soponaru ${ }^{2}$, Anamaria Ciubară ${ }^{3}$, Maria Bolat ${ }^{4}$, Magdalena Iorga ${ }^{5}$ \\ ${ }^{1}$ Pediatrie, Universitatea de Medicină şi Farmacie ,, Gr. T. Popa “, Iaşi \\ ${ }^{2}$ Universitatea ,Al. I. Cuza“", Iaşi \\ ${ }^{3}$ Psihiatrie, Universitatea de Medicină şi Farmacie ,, Gr. T. Popa “, Iaşi \\ ${ }^{4}$ Universitatea de Medicină şi Farmacie „, Gr. T. Popa “, Iaşi \\ ${ }^{5}$ Psihologie, Universitatea de Medicină şi Farmacie „, Gr. T. Popa “, Iaşi
}

\begin{abstract}
REZUMAT
Endoscopia digestivă, una dintre cele mai frecvente investigații invazive în gastroenterologia pediatrică, nu este lipsită de riscuri. Complexul de măsuri necesare acestei manevre cuprinde: evaluarea corectă a bolnavului ținând seama de indicațiile şi contraindicațiile endoscopiei, obținerea consimțământului informat, pregătirea psihologică a părinților/copilului, aplicarea unor restricții dietetice, profilaxia infecțiilor. De asemenea, trebuie ales tipul de anestezie, monitorizarea continuă intra şi post-procedurală pentru evitarea complicațiilor legate de procedură sau de reacții adverse medicamentoase.
\end{abstract}

Cuvinte cheie: anestezie, endoscopie digestivă, copil

\section{INTRODUCERE}

Progresele în endoscopie şi anestezie au permis efectuarea de endoscopii digestive la copii încă din 1960. În ultimele decenii, numărul endoscopiilor a crescut considerabil. Gastroenterologii pediatri, medicii anestezişti şi asistentele de endoscopie digestivă formează echipe specializate care sunt prezente în diferite unități medicale şi care permit realizarea unor proceduri sigure şi eficiente. Gastroenterologia pediatrică a devenit o subspecialitate în multe țări din Uniunea Europeană. Procedurile efectuate cel mai frecvent pentru evaluarea şi stabilirea diagnosticului afecțiunilor tractului gastro-intestinal sunt endoscopia digestivă superioară (EDS) şi colonoscopia. Videocapsula sau enteroscopia cu dublu balon sunt investigații potrivite pentru evaluarea intestinului subțire, alternative la rezonanța magnetică după enterocliză. (1) Polipectomia, recuperarea corpilor străini, plasarea endoscopică a gastrostomiei percutane (PEG), colangiopancreatografia endoscopică retrogradă sau ligatura varicelor esofagiene sunt manevre de endoscopie digestivă terapeutică ce necesită abilităţi practice şi dotări tehnice speciale; în centre specializate unele dintre acestea pot fi realizate încă din perioada neonatală. (1) Spre deosebire de endoscopia practicată la adult, cea realizată la pacientul pediatric mic este de obicei efectuată sub anestezie generală pentru a reduce stresul fizic şi emoțional provocat de procedură.

\section{CONSIMŢĂMÂNTUL INFORMAT ŞI PREGĂTIREA PSIHOLOGICĂ}

Ca orice procedură medicală, endoscopia digestivă superioară este legată de îndeplinirea unor criterii de ordin psihologic şi etic. Consimțământul informat al părinților şi copilului trebuie obținut 
înainte de efectuarea investigației. Atât copiii, cât şi părinții trebuie să primească toate informațiile legate de beneficiile şi de riscurile investigației, iar sectiunile importante trebuie prezentate și în scris. Semnarea consimțământului duce la o relație medic-pacient bazată pe încredere. De asemenea, acesta reprezintă şi un document juridic. În țara noastră, obținerea consimțământului informat este stipulată în Legea nr. 46/21 ianuarie 2003 privind drepturile pacienților de a primi informații referitoare la serviciile medicale şi modul de aplicare al acestora şi, de asemenea, la identitatea şi statutul profesional al furnizorului de sănătate. Consimțământul părinților reprezintă o permisiune informală explicită, acesteia adăugându-i-se în mod obligatoriu acordul/acceptul pacientului minor. Desigur, în condițiile recunoaşterii existenței unor diferențe, în prezent se consideră că, începând cu vârsta de 7 ani acesta poate înțelege scopul explorării, la 10 ani riscurile acesteia şi dreptul de refuz, iar după 14 ani maturitatea morală şi intelectuală ca şi capacitatea de înțelegere, gândirea abstractă sau evaluarea ipotetică se apropie de cea a adultului, permițând astfel decizii responsabile. La vârstele mai mici, sub 7-10 ani, părinții şi aparținătorii legali sunt cei cărora le aparține responsabilitatea refuzului sau suspendării intervenției. Comunicarea şi obținerea acordului copilului sunt influențate de prezența sau absența celor apropiați sau răspunzători de el. Situații aparte se întâlnesc la pacienții pediatrici cu dezvoltare intelectuală deficitară, cu tulburări psihice, la copiii orfani lipsiţi de un reprezentant legal sau la cei instituționalizați. Adolescenții consumatori de alcool sau droguri, sau membri ai unor secte, ca şi alți pacienți aflați în situații de urgență cu o stare generală alterată ce nu permite pierderea timpului pentru obținerea avizului de la aparținători, reprezintă o categorie aparte. Consimțământul informat reprezintă un document legal ataşat obligatoriu foii de observație, fiind semnat şi datat. (1) Conținutul acestuia cuprinde diagnosticul cât mai complet şi prognosticul afecțiunii pentru care se execută endoscopia, tipul şi descrierea procedurii, inclusiv a sedării/anesteziei preliminare, necesitatea şi beneficiile procedurii, neplăceri fizice, disconfort, complicații - severitate, incidență, riscuri şi prognosticul afecțiunii în caz de refuz. Limbajul utilizat de medic trebuie să fie cât mai simplu și clar, adaptat nivelului de înțelegere al părinților. Acestora trebuie să li se explice în termeni cât mai exacți avantajele, dar și limitele metodei. Înțelegerea metodelor şi a pregătirilor pentru endoscopia digestivă din partea copiilor şi a părinților acestora permite ca procedura să fie efectuată fără dificultăți şi cu rezultate satisfăcătoare. Copiii au nevoie de diferite forme de sedare pentru a fi cooperanți şi pentru a se simți cât mai confortabil. Endoscopistul ar trebui să decidă tipul de anestezie folosit pe baza experienței personale. Părinții şi copiii prezintă adesea anxietate de separare în timpul procedurii. În perioada pre-procedurală este necesară prezența părinților; aceasta a fost aprobată şi în perioada de inducere a anesteziei. (2) În timpul fazei de inducție, pierderea inhibiţiei şi a anxietăţii este frecventă. Părinţii informați pot ajuta la reducerea anxietăţii copiilor lor. Pregătirea psihologică pentru endoscopia pacientului pediatric ar trebui sa țină cont de particularitățile fiziologice, psihosociale şi emoționale ale pacienților pediatrici, precum şi de reactivitatea părinților acestora. Un psiholog clinician poate asista copilul şi familia pentru ca aceştia să suporte mai bine procedura (3). Anxioliticele reduc semnificativ starea de agitație psihomotorie a pacienților şi a familiilor acestora (4). Consilierea înainte de efectuarea procedurii reduce semnificativ anxietatea pacientului şi a familiei sale şi determină un grad mai mare de complianță din partea acestora. Principalii factori importanți pentru familie sunt apariția unei posibile dureri, dar mai ales riscurile sedării şi anesteziei, ceea ce face ca părinții să fie mult mai precauți în a-şi da consimțământul. Pentru copiii mai mari, efectuarea unor şedințe de relaxare şi antrenament autogen pot avea efecte considerabile asupra comportamentului micilor pacienți pe parcursul procedurii $(5,6)$.

\section{EVALUAREA CLINICĂ ŞI INVESTIGAȚII PRE-PROCEDURALE}

Evaluarea clinică şi examenul fizic sunt făcute sistematic, punându-se accent pe aparatul respirator. Examinarea eventualelor piercinguri orale, a dinților temporari cu rizaliză şi a gradului de hipertrofie amigdaliană sunt foarte importante. $\mathrm{O}$ atenție sporită trebuie acordată în special copiilor cu vârsta între 6 şi 8 ani, interval în care incisivii centrali şi laterali atât maxilari, cât şi mandibulari se află în perioada de mobilitate accentuată, premergătoare căderii acestora. În cadrul manevrelor de inserare a piesei bucale din plastic şi menținerea acesteia pe toată durata investigației, dinții care prezintă mobilitate pot fi crăpați, fracturați sau dislocați. La pacienții purtători de aparate dentare fixe (brackets), în timpul EDS putem menționa ca şi accident stomatologic deplasarea sau chiar îndepărtarea unui brackets de pe dinte, consecință a poziționării defectuoase a piesei bucale. Acest fapt însă nu este considerat a fi grav, deoarece brackets-ul poate fi 
repoziționat în condiții normale. Ca modalitate de protecție, aceşti pacienți pot purta dispozitive speciale din plastic aplicate pe dinte şi care prezintă un şant la nivelul aparatului dentar, asemănătoare celor utilizate de persoanele care cântă la instrumente de suflat (trompetă, saxofon etc.) purtători de aparate dentare. Dinţii temporari cu rizaliză sau piercingul pot fi accidental dislocaţi şi pot cauza complicații din cauza ajungerii acestora în căile respiratorii ale pacientului. Amigdalele hipertrofice pot induce apnee obstructivă la pacienții sedați. (7) Endoscopia este contraindicată în cele mai multe cazuri de coagulopatie severă sau alte boli sistemice severe coexistente. Se recomandă teste de laborator precum grupul sanguin, hemoleucograma completă, testele funcționale hepatice, electroliții şi parametrii de coagulare. Pacientul trebuie monitorizat cu atenție şi dozele în care se administrează sedativele trebuie reduse în cazul alterării funcției hepatice. Contraindicaţiile absolute pentru endoscopie includ colapsul cardiovascular, instabilitatea căilor respiratorii, deteriorarea pulmonară sau a statusului neurologic, perforația digestivă, peritonita şi traumatismele cervicale. În absența consimțământului informat semnat sau a personalului medical competent, endoscopia ar trebui să fie amânată sau anulată. Contraindicații relative sunt intervenția chirurgicală digestivă recentă, obstrucția intestinală, coagulopatia, trombocitopenia severă, prematuritatea şi ingestia de alimente (8). Episoadele hipoglicemice ale pacienților cu diabet zaharat insulino-dependent pot influența desfăşurarea în condiții optime a actului endoscopic; aceşti pacienți au prioritate în efectuarea endoscopiei şi sunt sfătuiţi să reducă doza de insulină în dimineața de dinaintea procedurii. La un copil cu hematemeză se recomandă o radiografie abdominală simplă pentru a exclude prezența unei eventuale obstrucții intestinale sau a unei perforații (9).

\section{RESTRICȚII DIETETICE}

Pentru a reduce potențialul de aspirație al conținutului gastric, în timpul sedării este necesar repausul alimentar pre-procedural. Pregătirea intestinală depinde de investigația planificată şi de vârsta pacientului. Se recomandă ca pacienții să nu consume solide cu şase ore înainte şi lichide cu două până la patru ore înainte de procedură. În afecțiuni precum acalazia cardiei sau întârzierea evacuării gastrice, durata poate creşte pentru a evita riscul de aspirație datorat resturilor alimentare din esofag sau stomac. (10) Conform Academiei Americane de Pediatrie şi Societăţii Americane de
Anestezie, copiii ar trebui să consume lichide (inclusiv lapte matern, dar nu formulă de lapte) cu până la două-trei ore înainte de sedare pentru a evita deshidratarea. Copiii mai mici de şase luni pot primi formula de început cu până la 4-6 ore şi alte lichide cu până la două ore înainte de sedare. Pacienții de peste şase luni ar trebui să evite consumul de lichide şi solide cu 6-8 ore înainte de sedare. $(11,12)$

În ceea ce priveşte colonoscopia, pregătirea inadecvată a intestinului este responsabilă de până la o treime din totalul procedurilor incomplete. (13) Nu există ghiduri naționale pentru pregătirea colonoscopiei. Sunt disponibile diverse regimuri bazate pe clismă evacuatorie sau pe laxative. Ambele metode se bazează de obicei pe cooperarea pacienților pediatrici. Polietilenul glicol (PEG) este utilizat cel mai frecvent ca şi agent de evacuare al colonului la copii. Soluția de PEG 3.350 se utilizează în doza de $1,5 \mathrm{~g} / \mathrm{kg}$, timp de 4 zile înainte de procedură, cu dieta bazată exclusiv pe lichide în ziua 4 . $(14,15)$

\section{ANTIBIOPROFILAXIA}

În conformitate cu ghidurile Asociației Americane a Inimii (AHA) şi ale Societății Americane de Endoscopie Digestivă (ASGE), profilaxia cu antibiotice (Tabelul 1) este recomandată doar la anumite categorii de pacienți cu risc cardiac înalt. (16) Aceştia sunt purtătorii de proteze valvulare, pacienții cu antecedente de endocardită bacteriană, malformațiile congenitale de cord la care încă nu s-a intervenit chirurgical sau cele operate în primele 6 luni după intervenție sau cu defecte reziduale în vecinătatea protezei. Următoarele condiții pot beneficia, de asemenea, de o profilaxie cu antibiotice:

TABELUL 1. Utilizarea antibioticelor pentru profilaxie conform ASGE şi AHA (2007)

\begin{tabular}{|c|c|c|}
\hline Situații clinice & Antibiotic & Doze \\
\hline $\begin{array}{l}\text { Capacitatea de } \\
\text { administrare orală } \\
\text { a antibioticului }\end{array}$ & Amoxicilină & 50 mg/kg \\
\hline \multirow{2}{*}{$\begin{array}{l}\text { Incapacitatea de } \\
\text { administrare orală } \\
\text { a antibioticului }\end{array}$} & Ampicilină & $50 \mathrm{mg} / \mathrm{kg}$ IM sau IV \\
\hline & $\begin{array}{l}\text { Cefazolin sau } \\
\text { ceftriaxone }\end{array}$ & $50 \mathrm{mg} / \mathrm{kg}$ IM sau IV \\
\hline \multirow{3}{*}{$\begin{array}{l}\text { Alergie la penicilină } \\
\text { sau ampicilină }\end{array}$} & Cephalexină & $50 \mathrm{mg} / \mathrm{kg}$ \\
\hline & Clindamicină & $20 \mathrm{mg} / \mathrm{kg}$ \\
\hline & $\begin{array}{l}\text { Azithromicină sau } \\
\text { clarithromicină }\end{array}$ & $15 \mathrm{mg} / \mathrm{kg}$ \\
\hline $\begin{array}{l}\text { Alergie la penicilină } \\
\text { sau ampicilină, sau } \\
\text { incapacitatea de } \\
\text { administrare orală } \\
\text { a antibioticului }\end{array}$ & $\begin{array}{l}\text { Cefazolină sau } \\
\text { ceftriaxone } \\
\text { Clindamicină }\end{array}$ & $\begin{array}{l}50 \mathrm{mg} / \mathrm{kg} \text { IM sau IV } \\
20 \mathrm{mg} / \mathrm{kg} \mathrm{IM} \text { sau IV }\end{array}$ \\
\hline
\end{tabular}


copiii imunodeprimați, cei cu şunturi ventriculoperitoneale şi cei cu cateter venos central. (17) În acelaşi timp, profilaxia endocarditei bacteriene subacute nu este indicată în endoscopia diagnostică, fiind rezervată doar intervențiilor terapeutice (plasarea PEG, scleroterapia varicelor esofagiene, dilatațiile stricturilor, ERCP, puncție-aspirație cu ac fin efectuată sub ghidaj eco-endoscopic) $(16,18)$.

\section{ANESTEZIA PACIENTULUI PEDIATRIC}

Examinarea endoscopică în lipsa anesteziei a fost documentată şi evaluată ca fiind sigură pentru copiii motivați. (19) Sedarea adecvată este o parte integrantă a unei proceduri endoscopice de calitate, reducând anxietatea şi durerea copilului. Pe de altă parte, sedarea inadecvată determină disconfort pacientului şi duce la examinarea incompletă. Procedurile endoscopice la copii şi adolescenţi sunt în general efectuate sub sedare conştientă sau anestezie generală. Avantajele sedării conştiente sunt păstrarea respirației spontane în timpul examinării şi a reflexelor de protecție ale căilor respiratorii. Conform Societății Americane de Anestezie (ASA), practicarea endoscopiei sub anestezia generală este recomandată pacienților cu boli sistemice severe sau status terminal. (15)

Copiii sunt mult mai susceptibili la complicații respiratorii din cauza rezistenței pulmonare crescute şi sunt mai sensibili la hipoxemie. La sugarii sub şapte luni riscul este mai mare din cauza respirației exclusiv nazale. Infecțiile respiratorii la copiii cunoscuți cu hiperreactivitate bronşică reprezintă o contraindicație absolută pentru anestezia din endoscopia electivă. Anestezia cu propofol pare a fi cea mai sigură şi mai convenabilă metodă. (20). Pentru a reduce anxietatea şi depresia la pacienții mai tineri, prezența părinților în cadrul pregătirii preprocedurale este de obicei esențială (2). A fost demonstrat că premedicația cu benzodiazepine reduce anxietatea care apare înaintea endoscopiei. Aceasta poate fi administrată oral sau inhalator. (21) Midazolamul poate reduce stresul emoțional declanşat de separarea de părinți şi poate ajuta pacienții să se simtă mai confortabil în timpul intervenției. (22) Midazolamul are avantajul de a se asocia cu o incidență scăzută a obstrucției căilor aeriene, deși pot apărea ocazional laringospasmul sau delirul. Se recomandă suplimentarea cu oxigen administrat pe mască. (23) Administrarea orală de midazolam este o metodă sigură şi eficientă de sedare care reduce semnificativ anxietatea şi îmbunătățeşte toleranța generală a copiilor supuşi unei EDS. (24) Alte substanțe utilizate sunt fentanilul şi remifentanilul.
Utilizarea propofolului se face pe scară tot mai largă din cauza profilului său farmacodinamic favorabil. Doza bolus de propofol este $1-3,5 \mathrm{mg} / \mathrm{kg}$, urmată de o perfuzie de $0,1-0,3 \mathrm{mg} / \mathrm{kg} /$ minut. Utilizarea propofolului este asociată cu o rată scăzută a efectelor adverse minore, de obicei reversibile şi care nu produc sechele. Efectele adverse majore ale propofolului sunt extrem de rare şi apar doar la anumiți pacienți. Selecția adecvată a cazurilor conduce la reducerea suplimentară a acestor riscuri. Un studiu recent a raportat că utilizarea de propofol şi midazolam în endoscopia digestivă la pacientul pediatric a fost la fel de sigură şi de eficace ca şi la pacienții adulți (25). În alegerea tipului de anestezie intervin o multitudine de factori ca starea pacientului, tipul procedurii (diagnostică versus terapeutică), nivelul anticipat de cooperare al copilului, preferințele părinților şi ale copiilor precum şi experiența endoscopistului. (26) Utilizarea pe scară largă a anesteziei în endoscopia digestivă a pacientului pediatric impune posibilitatea necesității de reanimare şi deci prezența echipamentelor de monitorizare în sala de endoscopie. Monitorizarea standard trebuie să includă parametri precum electrocardiograma, tensiunea arterială şi pulsoximetria. Pentru a reduce la minimum reacțiile adverse, se recomandă titrarea medicamentelor sedative până când se atinge nivelul optim de sedare. În sala de endosocopie este necesară prezența a cel puțin doi asistenți. Un asistent va monitoriza căile respiratorii, va evalua semnele vitale şi va administra medicația, în timp ce celălalt va asista endoscopia diagnostică sau terapeutică. În sală trebuie să existe o sursă de oxigen cu presiune $100 \%$ şi sonde suplimentare de aspirație. Echipamentul de resuscitare trebuie să fie permanent disponibil, inclusiv sonde pentru intubație orotraheală şi defibrilator. $(15,26)$

TABELUL 2. Doze uzuale pentru medicația sedativă intravenoasă

\begin{tabular}{|c|c|c|}
\hline Medicație & Doze (mg/kg) & Maxim \\
\hline \multicolumn{3}{|c|}{ Benzodiazepine } \\
\hline Valium & $0,1-0,2$ & $10 \mathrm{mg}$ \\
\hline Midazolam & $0,1-0,4$ & $10 \mathrm{mg}$ \\
\hline \multicolumn{3}{|l|}{ Narcotice } \\
\hline Meperidine & $1-4$ & $200 \mathrm{mg}$ \\
\hline Fentanyl & $0,001-0,005$ & $200 \mathrm{mg}$ \\
\hline \multicolumn{3}{|l|}{ Altele } \\
\hline Pentobarbital & $2-6$ & $100 \mathrm{mg}$ \\
\hline Ketamine & $0,5-2$ & \\
\hline \multicolumn{3}{|l|}{ Propofol } \\
\hline Inducție & $2-2,5$ & \\
\hline Menținere & $0,125-0,3 \mathrm{mg} / \mathrm{kg} / \mathrm{min}$ & \\
\hline
\end{tabular}


Deoarece pentru unii părinți este mai dificil de acceptat ideea de efectuare a endoscopiei în condiții de anestezie generală este util ca medicul curant să prezinte corect şi complet sensibilitatea şi specificitatea acestei metode (spre exemplu, în tumorile gastrice ale adultului rata de diagnostic pozitiv este de $99,6 \%$ conform unor studii dar, pe de altă parte, există şi erori de diagnostic datorate prelevării defectuoase ale biopsiilor de mucoasă în infecția cu H. pylori sau boala celiacă). (27)

\section{CONCLUZII}

Endoscopia digestivă efectuată la pacientul pediatric este o procedură care a evoluat în ultimele decenii şi reprezintă un instrument de diagnosticare sigur şi eficient. Copiii de toate vârstele, inclusiv nou-născuții prematuri pot fi examinați, fiind astfel posibilă diagnosticarea mai precisă a unor entități cunoscute (boala celiacă), a tulburărilor emergente şi a unor afecțiuni „,provocatoare“ (utilizarea ERCP în colestaza neonatală). Desfăşurarea unor manevre sigure şi eficiente este condiționată de efectuarea corectă şi completă a tuturor etapelor premergătoare. 